\title{
TRADE CREATION AND TRADE DIVERSION EFFECTS: THE CASE OF THE ASEAN PLUS SIX FREE TRADE AREA
}

\author{
Rossanto Dwi Handoyo*, Lilik Sugiharti*, Miguel Angel Esquivias** \\ *Department of Economics, Faculty of Economics and Business, Universitas Airlangga, Surabaya, \\ Indonesia \\ ${ }^{* *}$ Corresponding author. Department of Economics, Faculty of Economics and Business, Universitas \\ Airlangga, Surabaya, Indonesia. Email: miguel@feb.unair.ac.id
}

\begin{abstract}
This study examines whether trade agreements promoted under the ASEAN+6 over the period 2007-2017 supported trade creation and/or trade diversion effects within three export product groups, namely, manufactured goods, primary products, and natural resources-based goods. Using a gravity model, we note that primary products offer pure trade creation (greater intra-bloc and extra-bloc trade). Manufactured products experienced trade creation in intra-bloc and extrabloc exports, while natural resources-based goods show trade creation in intraregional exports and trade creation in imports from extra-bloc.
\end{abstract}

Keywords: Gravity model; Panel data; Trade creation and trade diversion effects; PMML; Technology intensity; Food; Manufacturing.

JEL Classifications: C23; F10; F14.

Article history:

Received : October 10, 2019

Revised : August 14, 2020

Accepted : October 29, 2020

Available Online: March 31, 2021

https://doi.ord/10.21098/bemp.v24i1.1163. 


\section{INTRODUCTION}

This study applies the gravity model to analyze whether the Free Trade Agreements (FTAs) promoted by the 10 members of the Association of Southeast Asian Countries (ASEAN) and the six strategic members (China, India, Japan, South Korea, Australia, and New Zeeland), which we refer to as ASEAN+6, have led to trade creation and/or to trade diversion effects across three groups of products, namely, manufactured goods, natural resource-based goods, and primary products. The study also questions the intra-ASEAN +6 trade effects arising from the slowdown in the period of 2008-2010, the fall of commodity prices (2009-2012), and the downturn in the global trade (2015-2016). Intra ASEAN+6 manufactured trade increased from US\$ 1.09 trillion to nearly US\$ 1.7 trillion from 2007 to 2017. By contrast, intra-trade within the natural resource-based goods domain fell from the 2007 level of US $\$ 380$ billion to US $\$ 372$ billion in 2017, while that of primary products fell from US\$174 billion to US\$ 160 billion over the corresponding period.

Although a late arrival in trade agreements, ASEAN has been expanding its trade negotiations, having incorporated six strategic bilateral partners in the ASEAN Free Trade Area; namely, China-ASEAN (2004), South Korea-ASEAN (2007), Japan-ASEAN (2008), Australia and New Zeeland-ASEAN (2010), and India-ASEAN (2010). As a result of this move, tariffs have been significantly reduced, and trade facilitation has been rapidly implemented (Pangestu \& Ing, 2016). The ASEAN Plus Agreements are currently focusing on the negotiation of a Regional Comprehensive Economic Partnership (RCEP), proposed as a single FTA between the 10 ASEAN members and the six partners. The recent rapid implementation of trade agreements in ASEAN initiates the empirical question of whether or not the creation of a more extensive free trade area has resulted in larger intra-regional trade.

The large expansion of trade agreements has encouraged a number of empirical and theoretical studies on FTAs, as the implementation of free trade deals is accompanied by trade creation and trade diversion effects, a concept introduced by Viner (1950). Trade creation describes how the application of a trade agreement could lead to a substitution of goods previously imported from nonmember countries or produced at a higher cost at home, by products from within country members. Tariff reduction, removal of barriers, and trade facilitation are drivers of trade flows in new deals (Kohl et al., 2016; Sugiharti et al., 2020). The switch to cheaper goods from inside country members could lead to a more efficient allocation of resources and possible welfare gains for intra-bloc members. By contrast, trade diversion represents a welfare loss where higher cost intra-bloc goods substitute cheaper goods from outside the bloc. Nevertheless, more often, both creation and diversion effects take place as a result of new FTAs (Taguchi, 2015), raising the question of which effect tends to dominate, and whether or not regional trade areas are worthwhile.

A number of previous studies have considered the effects of trade integration and employed the gravity trade model to analyze trade creation and deviation effect in an ex-post way, as initially proposed (see Pöyhönen, 1963; Timbergen, 1962). Additional theoretical groundwork for the gravity model was proposed by Anderson (1979) and further developed in other studies (Anderson and Van Wincoop, 2003; Baier and Bergstrand, 2004, 2007; Deardorff, 1998; Eaton and 
Kortum, 2002). The gravity trade model resulted in a useful approach to measure the effect of trade integration (Head and Mayer, 2014), often capturing the impact of trade policy through dummy variables representing the implementation of trade deals. Positive dummy FTA coefficients introduced in the gravity model suggest a higher than usual trade flows.

Previous empirical results suggest that some regional trade deals appear to be fragile as they are unstable (Oladi and Beladi, 2008). Besides, large differences in trade creation, deviation effects are observed across regions and partners (Baier et al., 2019), while some agreements offer no evidence of trade creation effects (Bhattacharyya and Mandal, 2014; Ghosh and Yamarik, 2004). Urata and Okabe (2014) and Cheong et al. (2018) argue that FTAs tend to promote both creation and diversion effects, with trade creation effects more common among developed countries than developing ones. Sectors associated with high technology and high skills often benefit more than sectors oriented to natural resources (Urata and Okabe, 2014).

Moreover, trade creation can be stronger for imports than for exports, while diversion effects can place intense pressure on domestic trade (Dai et al., 2014). Baier et al. (2019) have pointed out that some countries and industries suffer losses or enjoy fewer gains after joining an FTA deal, being rather reluctant about the benefits that FTAs provide. Lower gains are often found among the latecomers into trade deals (Anderson and Yotov, 2016) and those with high market power, as in the case of agricultural trade in ASEAN-China FTA (Schaak, 2015), which may resemble ASEAN countries, which are highly reliant on natural resources and are latecomers in liberalization.

Evidence for the ASEAN Plus One trade agreements suggests that FTAs have contributed to trade expansion, both for FTA members and non-members within the agricultural and manufactured goods sector, although at different rates (Devadason et al., 2015; Sheng et al., 2014; Yang and Martinez-Zarzoso, 2014). Korinek and Melatos (2009) found intra-bloc trade creation in agricultural goods in ASEAN, although no evidence of trade creation in agricultural trade with extra bloc countries. Taguchi (2015) found trade creation effects in all the ASEAN bilateral deals with each of the six strategic partners, although seeing significantly larger gains in the ASEAN-China deal than in those deals with the other five partners (e.g., India, Japan, and South Korea). Nevertheless, evidence also suggests losses across members, as in the case of ASEAN-India, where deciding to sign a trade deal during a recessionary period and accepting large concessions on tariff reductions resulted in a loss (Bhattacharyya and Mandal, 2016; Khurana and Nauriyal, 2017).

While several studies focus on the ASEAN Plus One deals (Sheng et al., 2014; Timsina and Culas, 2019), generally suggesting gains at the bilateral level, the ASEAN+6 as a single area (RCEP) remains as an empirical gap. A regional perspective is essential, considering the positive effects associated with broader coverage of the agreement (Ando and Urata, 2007; Sen et al., 2013; Taguchi, 2015). The trade dependence of the RCEP with extra-bloc countries also suggests the need to look at the RCEP trade effects with non-member countries (Devadason et al., 2015; Park, 2020; Sen et al., 2013). Besides, the high level of regional integration and the highly fragmented production and trade structure of the RCEP suggest 
looking at the region as a single bloc (Kimura and Obashi, 2016; Padilla et al., 2019; Purwono et al., 2020).

By employing a data panel including 16 partner countries and 22 extraregion countries, this paper aims to examine the trade creation and deviation effects arising from the FTA across the ASEAN+6 members. Trade agreements are incorporated in the gravity model, including a set of three dummy variables to capture the effects of the existent FTA on trade. One dummy variable captures intra-bloc trade, while the other captures export creation to extra-bloc. The third dummy variable captures the level of imports from extra-bloc, following Yang and Martinez-Zarzoso (2014). To account for the FTA endogeneity issue resultant from unobserved heterogeneity between trading countries along with unobserved dyad factors, country-specific effects are incorporated as exporter and importer dummy variables (Baier and Bergstrand, 2007). Dummy years (time effects) are employed to account for: (a) the global conditions most likely affecting trade flows (WTO, 2012; Yang and Martinez-Zarzoso, 2014); (b) the post-2007 global slowdown (20082010 period) (Timsina \& Culas, 2019); (c) the fall of commodity prices (2009-2012); and (d) the slowdown of global trade (2015-2016) (Bhattacharyya and Mandal, 2016).

The Poison Pseudo-Maximum Likelihood (PPML) model of Silva and Tenreyro (2006) is employed, as it is preferred as an appropriate tool in structural gravity equations with multilateral resistance terms (Anderson and Yotov, 2016; Saucier and Rana, 2017; Taguchi, 2015; Yang and Martinez-Zarzoso, 2014). The PPML also allows handling zero trade flows and obtaining more stable estimates in the presence of endogeneity and heteroscedasticity (Fally, 2015; Khurana and Nauriyal, 2017).

The contributions of this paper are threefold. First, we use disaggregated trade data for specific groups of products to avoid underestimation of effects arising from the aggregation of unrelated goods. Three main groups of products are studied; namely, natural resources-based goods, primary products, and manufactured goods. Additionally, we replicate the gravity equation to three sub-categories of products aggregated, according to Lall's (2000) technological intensity groups; namely, high-tech, medium-tech, and low-tech goods. Trade effects on food products and agricultural raw goods are also incorporated. The estimation of trade effects at sub-categories of products helps as a robustness test, and to estimate whether more disaggregated data offer new insights at specific technology level.

Second, we treat the ASEAN+6 as a single integrated region as it is highly interconnected in production and trade. Several studies looking at the bilateral level may ignore the effects deriving from strong regionalization in trade characterizing the RCEP region. Third, we provide evidence on the need to incorporate specific time effects to capture the impact of shocks on trade. Overall, we point out that drivers of exports across groups, the effect of the implementation of FTAs, and reactions to global shocks differ across groups of products. Previous studies pointed out possible underestimation of trade effects derived from the aggregation of dissimilar goods (Cheong et al., 2018; Gil-Pareja et al., 2014; Urata and Okabe, 2014).

This study is timely, considering the current negotiation of the RCEP. While the agriculture and ASEAN Plus One effects within manufactured goods are often 
addressed (Sugiharti et al., 2020), this study offers the case of natural resources, primary products, and exports based on technological intensity. The slowness of trade in the last decade also provides a definite novelty to the literature on trade creation - trade deviation effects, as the global slowdown has played a decisive role in the distribution of welfare gains deriving from trade agreements (Bhattacharyya and Mandal, 2016).

The results suggest that the implementation of ASEAN +6 trade agreements lead to larger than usual intra-regional trade for all the goods studied. FTAs are trade creating on exports to non-regional partners in manufactured products (including high-tech and low-tech), primary goods, food, and agricultural raw goods. Larger exports to extra-bloc signals progress in competitiveness as a single production-based region. Larger than usual imports from non-members derived from agreements are identified in non-manufacturing (primary goods, natural resources, agricultural raw, and food). The only case for import diversion is under low-tech goods, suggesting that the FTAs re-directed trade from extra-bloc to intra-region. Additionally, we identify that distance has a larger negative effect on natural resource and primary products than on manufactured goods. Finally, we identify large negative shocks due to global shocks within the natural resources - primary goods, while the manufacturing sector was affected to a lesser extent.

Our results are in line with previous findings at the bilateral level on the manufacturing sector, who generally find trade creation effects (Khurana and Nauriyal, 2017; Sheng et al., 2014; Yang and Martinez-Zarzoso, 2014). We identify an overall strengthening of manufacturing trade in the ASEAN Plus region. We contribute to the literature on ASEAN trade by providing evidence on product groups not previously studied at the regional level. Specifically, we find large trade creation in high-tech goods and food, and import diversion in low-tech goods. Additionally, we identify that trade creation effects in ASEAN Plus were partly canceled out by shocks, especially for natural resource and primary goods. The literature on natural resource-related goods reveals high exposure to commodity prices (Hegerty, 2016) over the last decade, a volatile exchange rate affecting trade (Sugihart et al., 2020), and the slowdown in global demand, particularly affecting emerging countries (Baiardi et al., 2015; Serrano and Pinilla, 2010). We provide evidence on the impact of such exposures in the context of ASEAN trade.

The paper is organized as follows. Section II provides a discussion on methodology and data used in this study. In Section III, we discuss our main findings followed by the concluding remarks in the final section.

\section{DATA AND METHODOLOGY}

A. Data

In our study, we use annual data for a panel of 38 countries, covering 16 ASEAN+6 countries and 22 other non-trading partners over the period 2007 to 2017 (See Table 1). The ASEAN+6 is currently under revision, and metamorphosing into RCEP, a regional FTA among the 10 member states of the ASEAN (namely Brunei, Cambodia, Indonesia, Laos, Malaysia, Myanmar, Philippines, Singapore, Thailand, and Vietnam) and their six FTA partners (namely Australia, China, India, Japan, New Zealand, and South Korea). The core variables used in this study are exports 


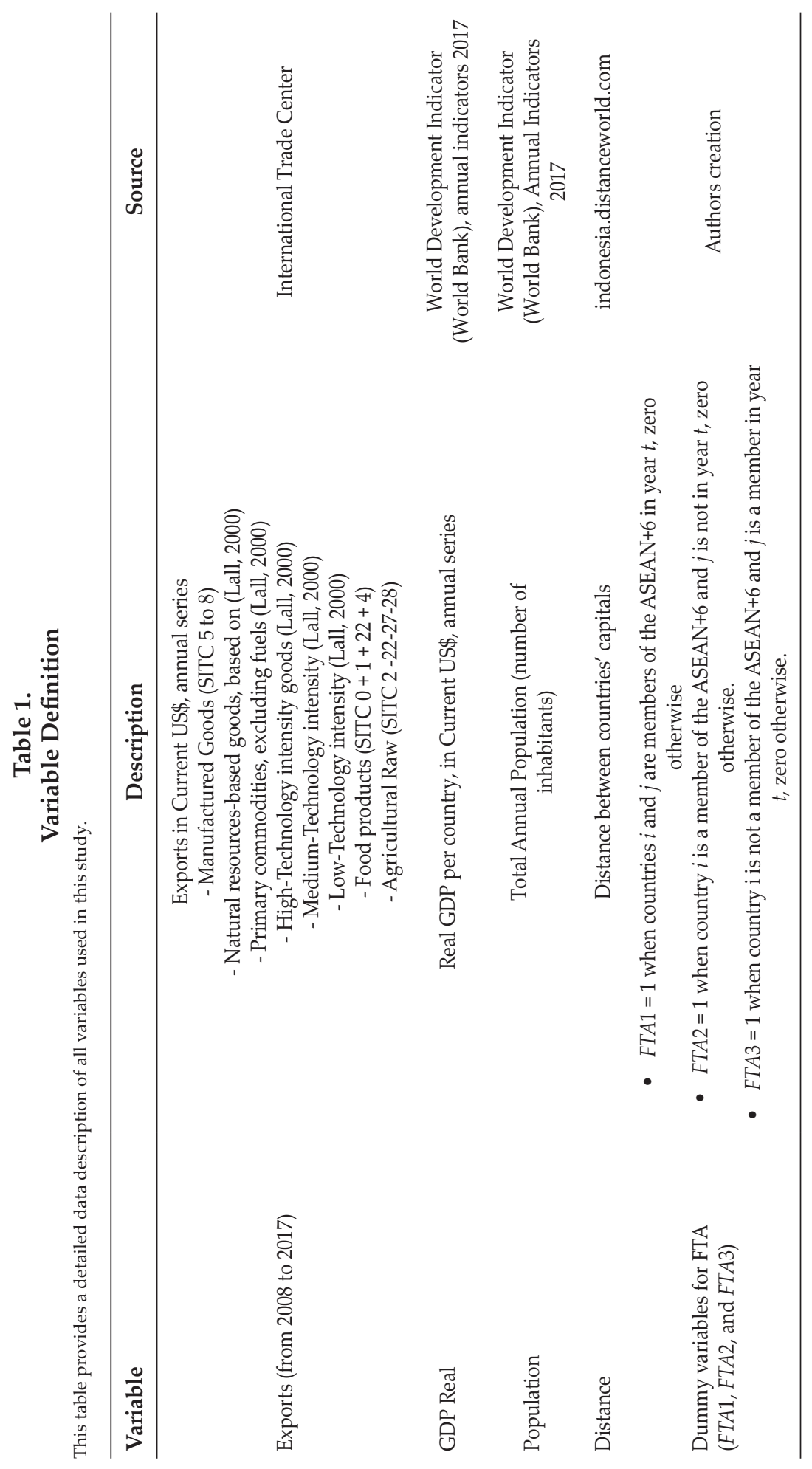




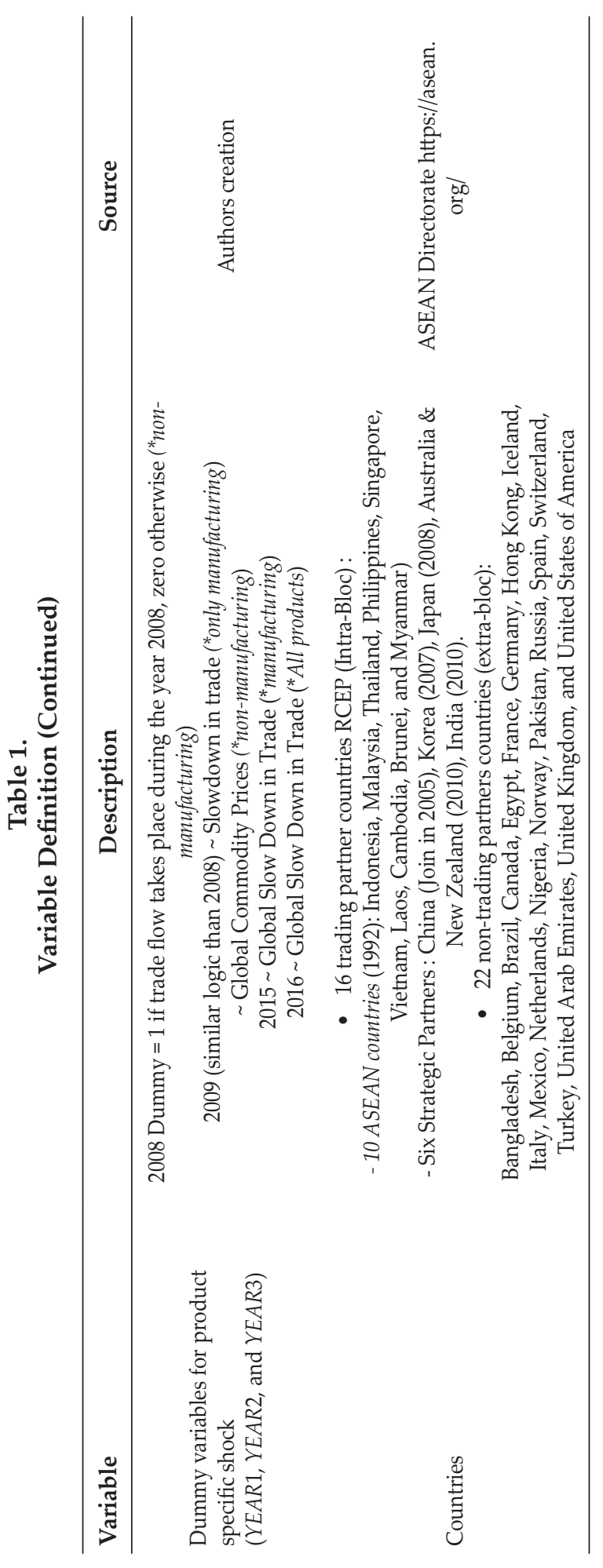


Table 2.

Summary Statistics

This table provides the summary statistics of variables employed. The variable notations are fully explained in Table 1.

\begin{tabular}{lccccc}
\hline Variable & Obs & Mean & Std, Dev & Min & Max \\
\hline Manufactured & 9,229 & $4,804,761$ & $19,200,000$ & 0 & $417,000,000$ \\
Primary Products & 8,657 & 613,889 & $2,074,363$ & 0 & $39,400,000$ \\
Natural Resources & 8,723 & $1,084,324$ & $3,080,057$ & 0 & $62,100,000$ \\
High-tech & 8,822 & $1,750,000$ & $8,670,000$ & 1 & $227,000,000$ \\
Medium-tech & 8,910 & $1,485,051$ & $5,328,533$ & 0 & $87,600,000$ \\
Low-tech & 9,075 & $1,028,948$ & $5,413,896$ & 0 & $151,000,000$ \\
Agricultural Raw & 7,127 & 136,000 & 567,000 & 11 & $12,800,000$ \\
Food & 7,337 & 417,000 & $1,390,000$ & 3 & $25,500,000$ \\
GDP & 9,229 & 1,610 & 2,680 & 5.67 & 17,300 \\
Population & 9,229 & 190,000 & 367,000 & 311,566 & $1,390,000$ \\
Distance & 9,229 & 8,088 & 4,623 & 378 & 19,889 \\
\hline
\end{tabular}

(measured in current US\$), real GDP (measured in current US\$), total annual population, and the distance between capitals of each country. We have formed three panels for our data analysis. These three panels are based on total exports of manufactured goods, natural resources-based goods, and exports of primary commodities (excluding fuel). A detailed description of the data is given in Tables 1 and 2.

\section{B. Methodology}

In order to examine the impact of trade creation and diversion on three groups of export goods, we estimate an augmented gravity model. In a generalized gravity equation, trade is positively related to the economic size and population of markets and negatively associated with distance. Other factors, commonly integrated as independent variables, can also promote or lower trade. The standard gravity model is further extended by Baier and Bergstrand (2007) and Soloaga and Winters (2001) by including a set of dummy varaibles which captures the effect of trade policies of membership countries of FTA. Therefore, an augmented version of the gravity model takes the following form:

$$
\begin{aligned}
\operatorname{Exp}_{i j t}= & \beta_{0}+\beta_{1} G D P_{i t}+\beta_{2} G D P_{j t}+\beta_{3} P_{i t}+\beta_{4} P_{j t}+\beta_{5} D_{i j}+\beta_{6} F T A 1_{i j t}+ \\
& \beta_{7} F T A 2_{i j t}+\beta_{8} F T A 3_{i j t}+\gamma_{i}+\delta_{j}+\varepsilon_{i j t}
\end{aligned}
$$

where $\operatorname{Exp}_{i j t}$ represents exports from country $i$ (exporter) to country $j$ (importer) at time (year) $t ; G D P_{i t}$ is the real annual GDP of country $i$ (exporter) at time (year) $t$, and GDP ${ }_{j t}$ captures the real annual GDP of importer country $j ; P_{i t}$ is the total annual population of country $i$ (exporter) at time $t ; P_{j t}$ is the population of the importer country $(j)$ at time $t$; and $D_{i j}$ is distance between country capitals of country $i$ (exporter) and country $j$ (importer). All these core variables are taken in 
natural logarithm form. FTA1, FTA2, and FTA3 are a set of dummy variables that capture intra-bloc and extra-bloc effects (see by Baier and Bergstrand, 2007 and Soloaga and Winters, 2001 for more detail) . More specifically, FTA1 is a dummy variable that takes the value one when both exporter and importer countries are in a trade agreement and zero otherwise; FTA2 is a dummy variable which takes the value one when only the exporter country (and not the importer country) is a member of the FTA and zero otherwise; and FTA3 represents a dummy variable which takes a value one when only the importer country (and not the exporter country) is a member of the FTA and zero otherwise. Additionally, $\gamma_{i}$ controls for exporter country effects while $\delta_{j}$ controls for importer country effects.

Moreover, Equation (2) is further extended in order to capture the product specifc trade shocks arising from global conditions (see Khurana \& Nauriyal, 2017; Timsina \& Culas, 2019). More specifically, these trade shocks are captured by including dummy varaibles for those years where we find a substantial decrease in trade with respect to each of the products (namely, manufactured, primary and resource- based goods) considered in this study. Thus, our empirical model takes the following form:

$$
\begin{aligned}
& \operatorname{Exp}_{i j t}=\beta_{0}+\beta_{1} G D P_{i t}+\beta_{2} G D P_{j t}+\beta_{3} P_{i t}+\beta_{4} P_{j t}+\beta_{5} D_{i j}+\beta_{6} F T A 1_{i j t}+ \\
& \beta_{7} F T A 2_{i j t}+\beta_{8} F T A 3_{i j t}+\beta_{9} \text { Year } 1+\beta_{10} \text { Year } 2+\beta_{11} \text { Year } 3+\gamma_{i}+\delta_{j}+\varepsilon_{i j t}
\end{aligned}
$$

Here, Year1, Year2, and Year3 are three dummy variables which capture product specific shock in specific years. For instance, in the case of manufactured goods, Year1, Year2, and Year3 represent dummy variables for years 2009 (countries policy interventions amid periods of distortion, see Pieters \& Swinnen, 2016) and 2015 and 2016 (slow growth in global trade), respectively. On the other hand, for natural resources-based and primary goods, Year1, Year2, and Year3 represent dummy variables for years 2008 and 2010 (countries policy interventions amid periods of distortion), and 2016 (slow growth in global trade), respectively. We use the PPLM estimator to estimate Equations (2) and (3) as it controls for heteroskedasticity and it also helps in solving the issues of zero trade flows (see Silva \& Tenreyro, 2006).

\section{MAIN FINDINGS}

A. Trade creation and trade diversion effects

The FTA dummy variables in Equations (2) and (3) capture the effects of trade creation or diversion in the RCEP region, both within the bloc and outside the bloc. The combined effects arising from three different FTA dummy variables indicate the intra-bloc and extra-bloc effects. As discussed earlier, we have produced results for three different groups of export goods. In addition, we have applied fixed effects PPLM with and without a dummy variable that controls for time effects (shocks). We report these results in Table 5. For ease of exposition, the coefficients from Equations (2) and (3) are presented in percentage terms $[\exp ($ FTAcoefficient -1$) x 100]$ as in Martínez-Zarzoso et al. (2009). The Net Trade Creation is computed as $N T C=(\exp (F T A 1+F T A 2+F T A 3)-1)^{*} 100$. 
Table 3.

Trade Creation and Diversion Effects

In this table, we report results obtained by estimating Equation (2): $\operatorname{Exp}_{i j t}=\beta_{0}+\beta_{1} G D P_{i t}+\beta_{2} G D P_{i t}+\beta_{3} P^{i t}+\beta_{4} P_{j t}+\beta_{5} D_{i j}+$ $\beta_{6} F T A 1_{i j t}+\beta_{7} F T A 2_{i j t}+\beta_{8} F T A 3_{i j t}+\gamma_{i}+\delta_{j}+\varepsilon_{i j t}$ and Equation (3): $\operatorname{Exp}_{i j t}=\beta_{0}+\beta_{1} G D P_{i t}+\beta_{2} G D P_{j t}+\beta_{3} P_{i t}+\beta_{4} P_{j t}+\beta_{5} D_{i j}+\beta_{6} F T A 1_{i j t}$ $+\beta_{7} F T A 2_{\mathrm{ijt}}+\beta_{8} F T A 3_{\mathrm{itt}}+\beta_{9} Y_{\text {ear } 1}+\beta_{10}$ Year $2+\beta_{11}$ Year $3+\gamma_{i}+\delta_{j}+\varepsilon_{i j t}$. We estimate these equations using fixed effects PPLM model. Intra-Bloc refers to country members within the FTA agreement and extra-bloc refers to countries not covered within the FTA agreement. Lastly, ${ }^{*}{ }^{* *}$, and ${ }^{* * *}$ indicats statistical significance at the $10 \%, 5 \%$, and $1 \%$ levels, respectively.

\begin{tabular}{|c|c|c|c|c|c|c|}
\hline \multirow[t]{2}{*}{ Export Goods } & \multirow[t]{2}{*}{ Equation } & \multirow[t]{2}{*}{ Estimator } & $\begin{array}{l}\text { Trade } \\
\text { Creation } \\
\text { (intra- } \\
\text { bloc) }\end{array}$ & $\begin{array}{c}\text { Export } \\
\text { creation } \\
\text { (intra to } \\
\text { extra bloc) }\end{array}$ & $\begin{array}{l}\text { Exports } \\
\text { from } \\
\text { extra- } \\
\text { bloc to } \\
\text { member }\end{array}$ & $\begin{array}{c}\text { Net } \\
\text { Trade } \\
\text { Creation }\end{array}$ \\
\hline & & & FTA1 & FTA2 & FTA3 & \\
\hline \multirow{2}{*}{ Manufactured } & (1) & PPLM, FE & $26.9 \%$ & $9.6 \%{ }^{*}$ & $4.1 \%$ & $36.8 \%$ \\
\hline & (2) & PPLM, FE, D_Year & $16.8 \%{ }^{* *}$ & $4.4 \% *$ & $1.0 \%$ & $21.2 \%$ \\
\hline \multirow{2}{*}{ Resource Based } & (1) & PPLM, FE & $32.4 \%^{* * * *}$ & $3.1 \%$ & $6.3 \%$ & $38.7 \%$ \\
\hline & (2) & PPLM, FE, D_Year & $37.0 \%^{* * * *}$ & $5.6 \%$ & $8.2 \%$ & $45.2 \%$ \\
\hline Primary & (1) & PPLM, FE & $24.1 \%^{* * *+*}$ & $12.1 \%^{*}$ & $19.0 \%^{*}$ & $55.2 \%$ \\
\hline Commodities & (2) & PPLM, FE, D_Year & $27.4 \%^{* * *}$ & $14.6 \%{ }^{* * *+}$ & $21.9 \%$ & $63.8 \%$ \\
\hline
\end{tabular}

The implication of our findings is as follows. For the three groups of products, there is an overall trade creation in exports for the ASEAN+6, captured using a dummy variable FTA1. Trade creation indicates the placement of agreement promoted trade flows at a faster rate than usual within 16 countries in the bloc. Trade creation suggests a gain in welfare for the ASEAN intra-bloc partners as the implementation of the FTA agreement leads to larger than common trade from within the bloc.

Additionally, in the case of manufactured goods, besides positive trade creation effects (intra-bloc), we find FTA2 is positive and statistically significant, which indicates an increase in exports to extra-bloc countries. According to the literature on the global value chain, Asian countries form a reliable and competitive production network, and Asia is at the center of the global value-chain in manufactured goods (Kimura and Obashi, 2016; Padilla et al., 2019). A more integrated ASEAN+6 may experience gains in regional competitiveness. The FTA3 dummy variable (import goods from outside the bloc) is reported statistically insignificant. Our findings are further supported by the export-based statistics reported in Table 3, which indicate that the largest trade expansion of manufactured goods over the period 2007 to 2017 was with ASEAN+6 FTA partners (intra-bloc).

Next, we discuss the findings obtained for resource-based goods. We report a statistically significant and positive sign on the dummy variable, FTA1, which signifies trade creation in exports. The effects of FTA2 (exports to extra-bloc countries) are found to be positive and statistically insignificant. On the other hand, imports from extra-bloc (represented by FTA3) are positive and statistically significant, indicating trade creation in imports. The results for resource-based goods suggest larger gains in exports due to deeper regionalization rather than globalization (see Sen et al., 2013), while a more integrated RCEP benefited extrabloc countries. 


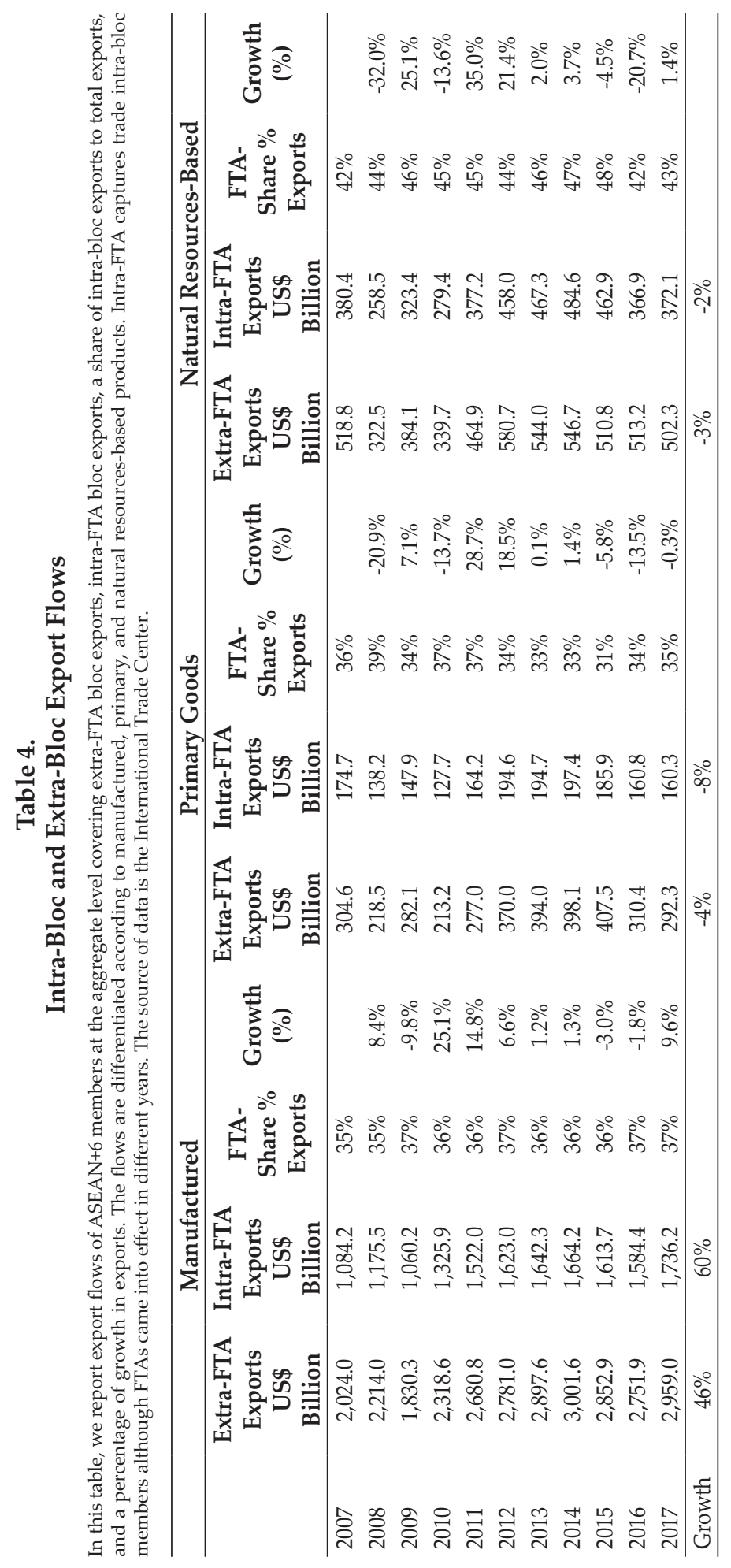


Furthermore, in the case of primary goods, there is evidence of positive and statiscially significant intra-bloc effects (FTA1, trade creation) and larger exports to extra-bloc countries (represented by FTA2). In other words, our findings suggest a pure trade creation (overall expansion of trade within and outside the bloc). Furthermore, a statistically significant and positive sign on the FTA3 dummy variable indicates that imports from outside the bloc have also increased, leading to trade creation in extra-bloc imports. Larger extra-bloc sourcing is associated with welfare gains through a lower cost of sourcing, more efficient supply of goods, and wider access to key inputs as noted in López Gonzalez (2016) for the ASEAN region.

It is worth noting that none of the FTA dummy varibales are found to be negative in sign. Therefore, we conclude that none of the three groups of products signal export diversion or trade diversion in imports. As noted in Dai et al. (2014) trade diversion effects could lead to sizeable internal trade alteration, first by diverting trade away from extra-bloc partners and from domestic producers to intra-bloc partners. Nevertheless, larger intra-regional trade may imply that local goods face stronger competition at home from regional partners.

Moreover, in the last column of Table 5, we have computed net trade creation for manufactured, natural resources-based goods and primary commodities using an approach proposed by Carrere (2006) and Martínez-Zarzoso et al. (2009). The net trade creation impact of the agreements is captured by the three FTA dummy variables: $(\operatorname{Exp}(F T A 1+F T A 2+F T A 3)-1)^{*} 100$. The three groups of products capture positive net trade creation effects. In the case of manufactured goods, the net marginal effect of trade creation is in the range of $21.2 \%$ (Equation 3) - 36.8\% (Equation 2). Our findings are consistent with those of Yang and Martinez-Zarzoso (2014), who also documented that manufactured goods experience pure trade creation effects under the ASEAN China FTA (1995-2010). However, they find larger trade creation and evidence of trade diversion in imports.

The net trade creation effects for resource-based goods are in the range of 38.7 $\%$ to $45.2 \%$. Intra-bloc trade is by far the largest contributor to trade expansion for resource-based goods. Imports from non-bloc members increased more rapidly as a result of a more integrated RCEP region. Primary commodities, by contrast, experienced all pure trade creation as the three concepts of trade increased. It is worth noting that exports from extra-bloc to RCEP members increased particularly rapidly, accounting for more than a third of net trade creation effects. 


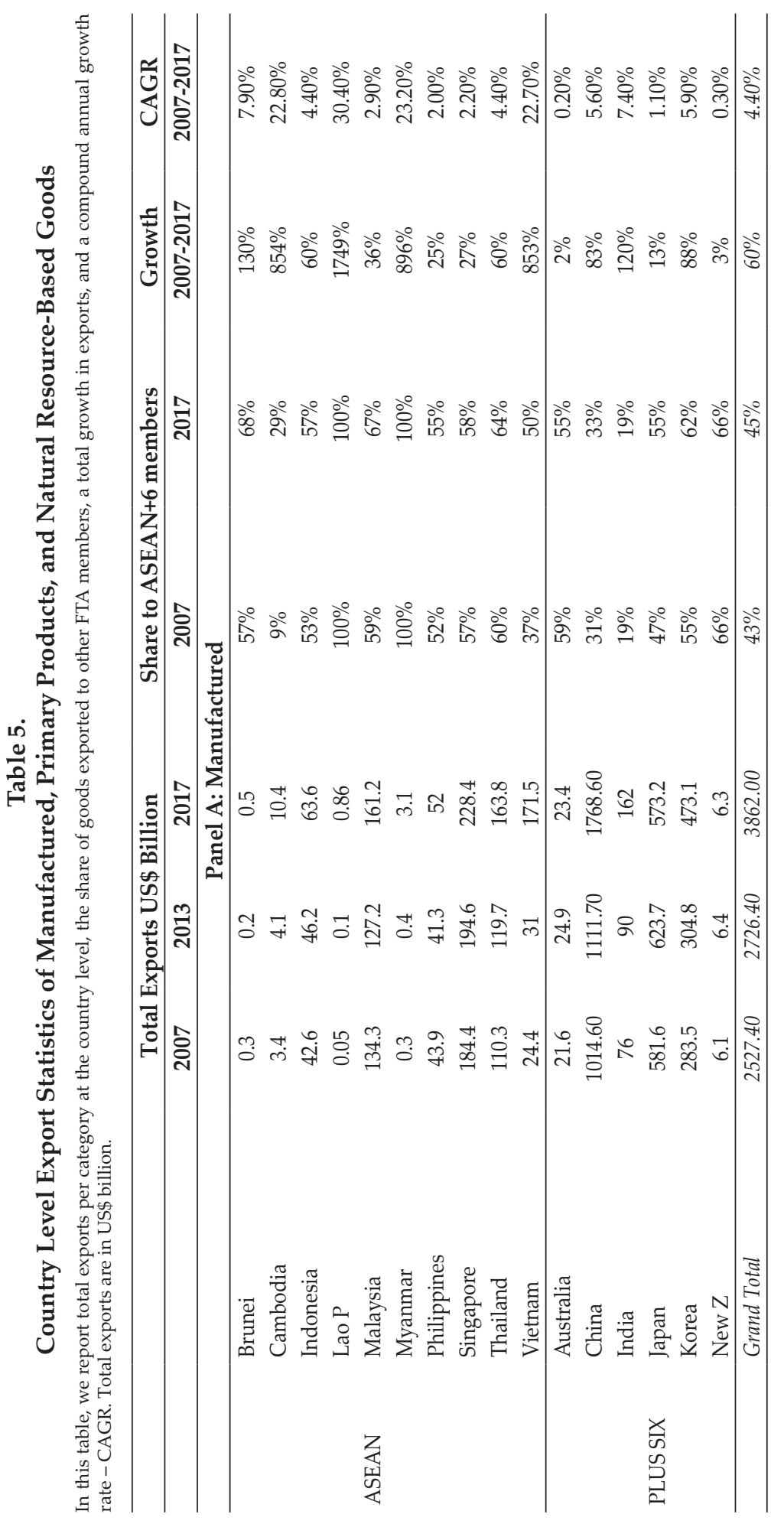




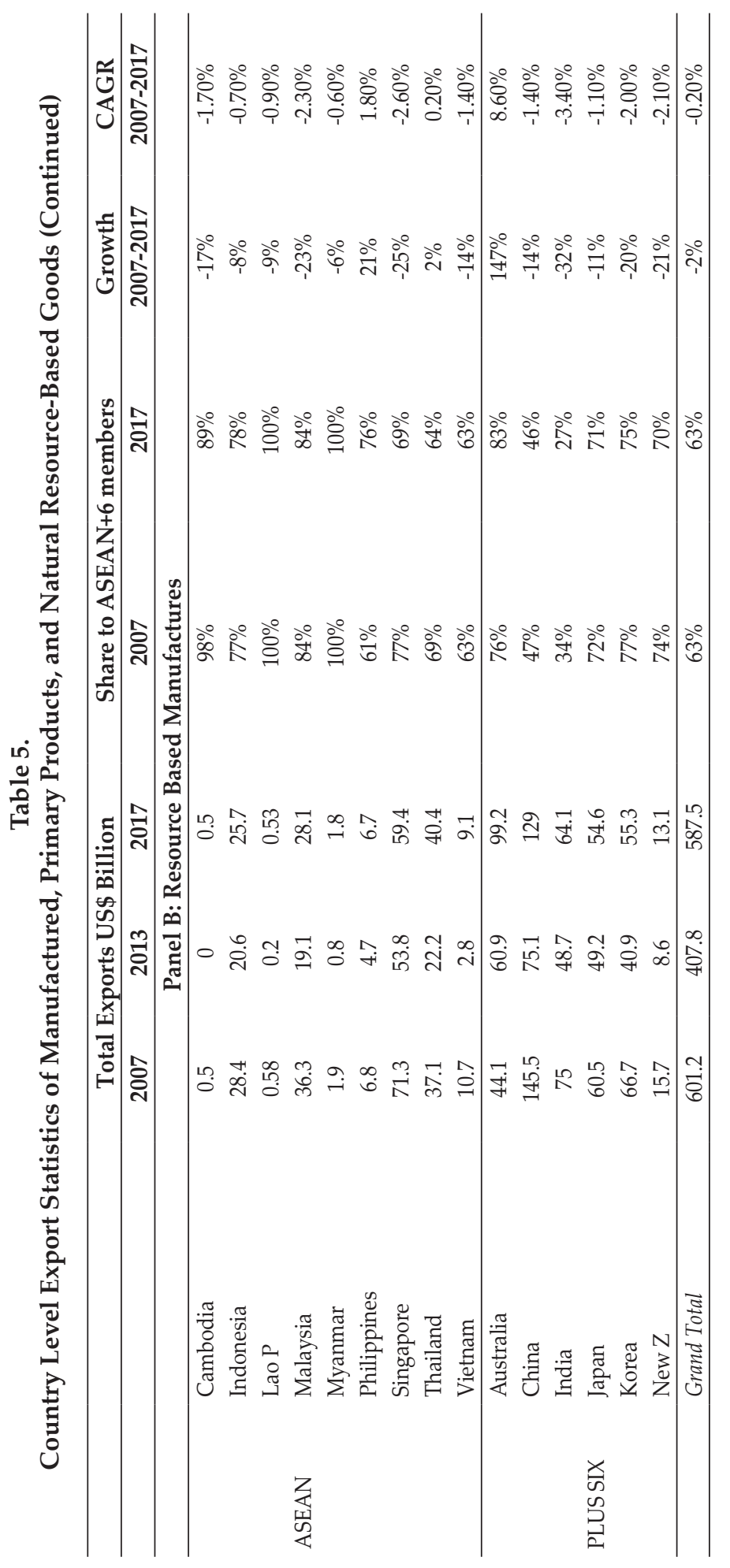




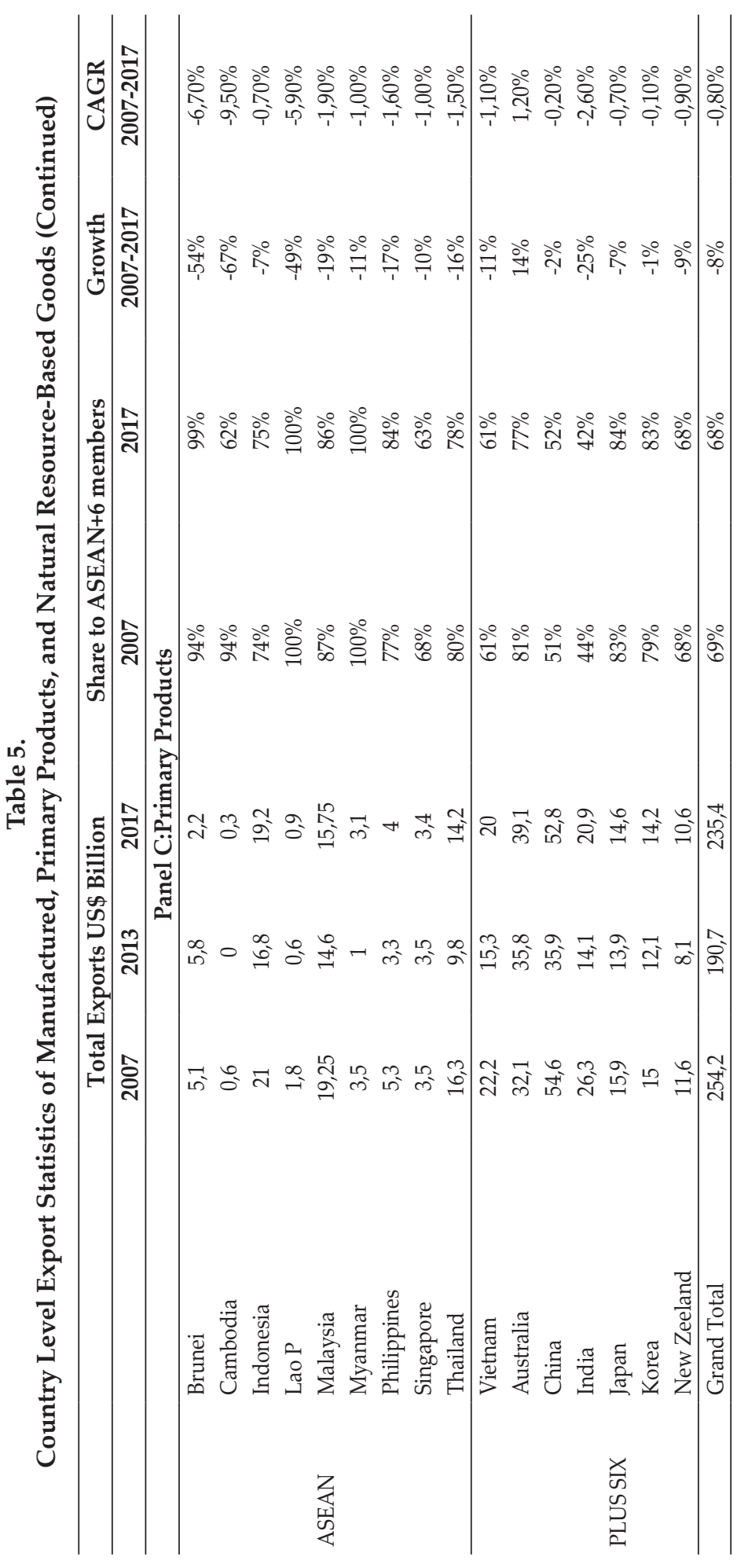


Next, we discuss results obtained for the core variables by estimating Equations (2) and (3). These results are tabulated in Table 6. Our findings indicate that the effect of both the GDP of the exporter (production capacity, GDP ${ }_{i}$ ) and the GDP of the importer (demand driver, GDP ${ }_{j}$ ) have important roles in explaining trade flows. We document that GDP for the exporter country has a positive and statistically significant effect on total exports of manufactured goods. For natural resources-based and primary goods only the specification without time shock (captured using Equation 2) provides significant results. Additionally, we find that the GDP for importer countries has a positive and statistically significant effect on total exports for all three groups. Income of the importer (proxied by GDP) has a stronger positive effect on export flows for natural resources-based and primary products than for manufactured goods. Our results support the findings of Sugiharti et al. (2020) and Baiardi et al. (2015), who documented a strong role of importer's income on demand for agricultural (resource based) products.

The second core variable in the gravity model is the total population of the exporter $\left(P_{i}\right)$ and importer $\left(P_{j}\right)$ countries. The total population of exporter countries has a statistically significant and negative effect on exports of primary goods. Our findings suggest that the target markets probably have strong internal supply of primary goods, widely available factor endowments (less import dependence), and diversification in production activities, as noted in Yang and Martinez-Zarzoso (2014). Large countries may be capturing the benefits of exports in primary commodities (China, India, Indonesia, the Philippines and Vietnam). On the other hand, in the case of natural resources-based goods, the relationship between exports and total population of importer countries is found to be positive and statistically significant. Large populations are then important drivers of demand for natural resources-based goods, consistent with Sugiharti et al. (2020).

Finally, we consider results related to the distance between the capital cities of trading partners. Overall, we find that the distance between capitals of trading partner countries has a negative impact on exports of manufactured, natural resources-based, and primary goods. Distance has a larger negative effect on natural resources-based goods and primary products than on manufactured goods. Our findings are consistent with those theoretical and empirical studies (Bergstrand et al., 2015), and indicate that the farther the distance, the smaller the trade flow (Baier et al., 2019; Magerman et al., 2015). High transportation costs, associated with long distances and time often lead to a decrease in the volume of trade (Yang \& Martinez-Zarzoso, 2014).

Finally, in addition to three core variables, we included dummy variables to capture and control for effects of global shocks (Crozet et al., 2015; WTO, 2012). More specifically, three yearly dummies for 2008, 2009, and 2010 captured the effect of countries' policy interventions amid periods of distortion (Pieters and Swinnen, 2016). Additionally, yearly dummy varibales for 2015 and 2016 capturethe slow growth in global trade, which resulted in lower export performance in ASEAN countries (see Lemoine and Unal, 2017).

Overall, we find that global shocks have a negative and statistically significant impact on exports of all three types of goods (manufactured, natural resourcebased, and primary goods). Trade shocks have a larger negative effect on natural resources-based goods and primary products than on manufactured goods, especially in 2008 and 2010. Our findings are supported by the country-specific 
export statistics reported in Table 4. It is quite evident that exports of natural resources-based and primary goods fell drastically in years 2008, 2010, and 2016. The intra-regional shocks were felt more substantially in natural resources-based, while the opposite (extra-bloc shocks) is more dominant in the case of primary goods.

Table 6.

Trade Determinants

In this table, we report results obtained by estimating Equations (2): $\operatorname{Exp}_{i j t}=\beta_{0}+\beta_{1} G D P_{i t}+\beta_{2} G D P_{i t}+\beta_{3} P_{i t}+\beta_{4} P_{i t}+\beta_{5} D_{i j}+$ $\beta_{6} F T A 1_{i j t}+\beta_{7} F T A 2_{i j t}+\beta_{8} F T A 3 i j t+\gamma_{i}+\delta_{j}+\varepsilon_{i j t}$ and Equation (3): $\operatorname{Exp}_{i j t}=\beta_{0}+\beta_{1} G D P_{i t}+\beta_{2} G D P_{i t}+\beta_{3} P_{i t}+\beta_{4} P_{i t}+\beta_{5} D_{i j}+\beta_{6} F T A 1_{i j t}$ $+\beta_{7}$ FTA $2_{i j t}+\beta_{8} F T A 3_{i j t}+\beta_{9}$ Year $1+\beta_{10}$ Year $2+\beta_{11}$ Year $3+\gamma_{i}+\delta_{i}+\varepsilon_{i j t}$. We estimate these equations using fixed effects PPLM model. Lastly, $* * * * * * * *$ indicate statistical significance at the $1 \%, 5 \%$, and $10 \%$ levels, respectively.

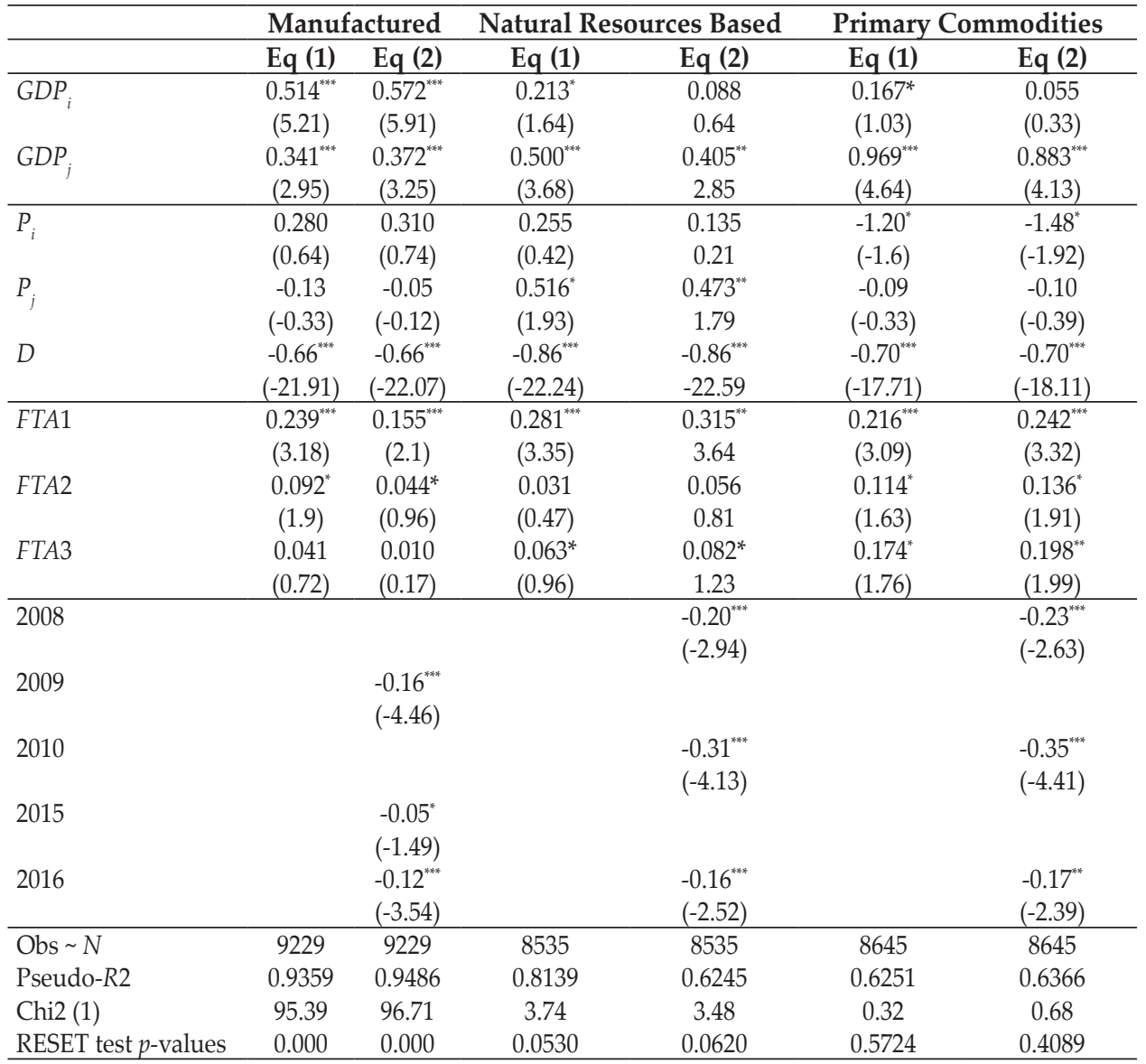

B. Robustness check

In this section, we follow Lall's (2000) technological intensity grouping method and further disaggregate manufactured products into three sub-categories (hightech, medium-tech, and low-tech goods). Additonally, we further categorise nonmanufactured products (natural resources-based and primary products) into two sub-categories, namely food and raw agricultural goods. Our estimation approach remains same as discussed earlier in Section II. These results are reported in Table 7. 


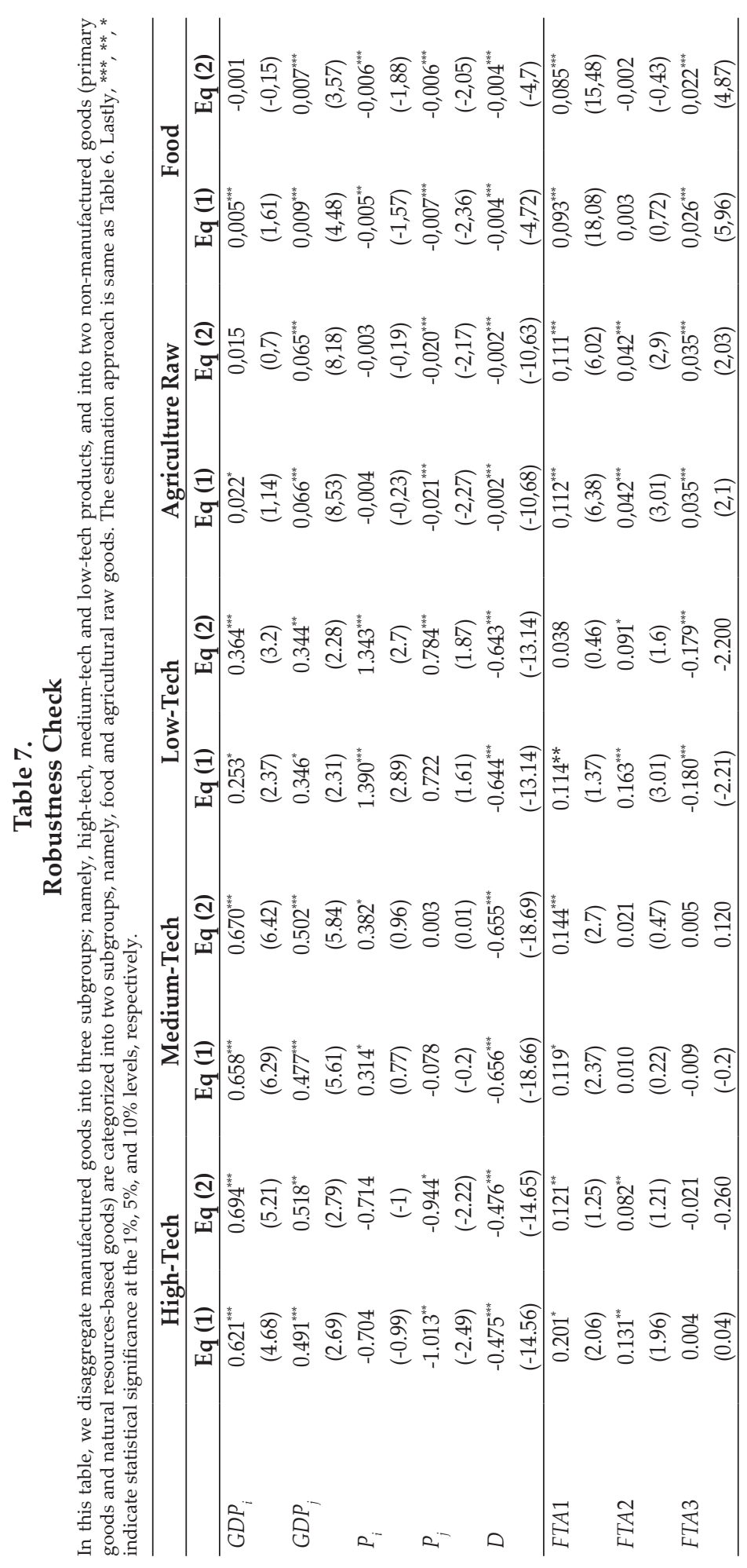




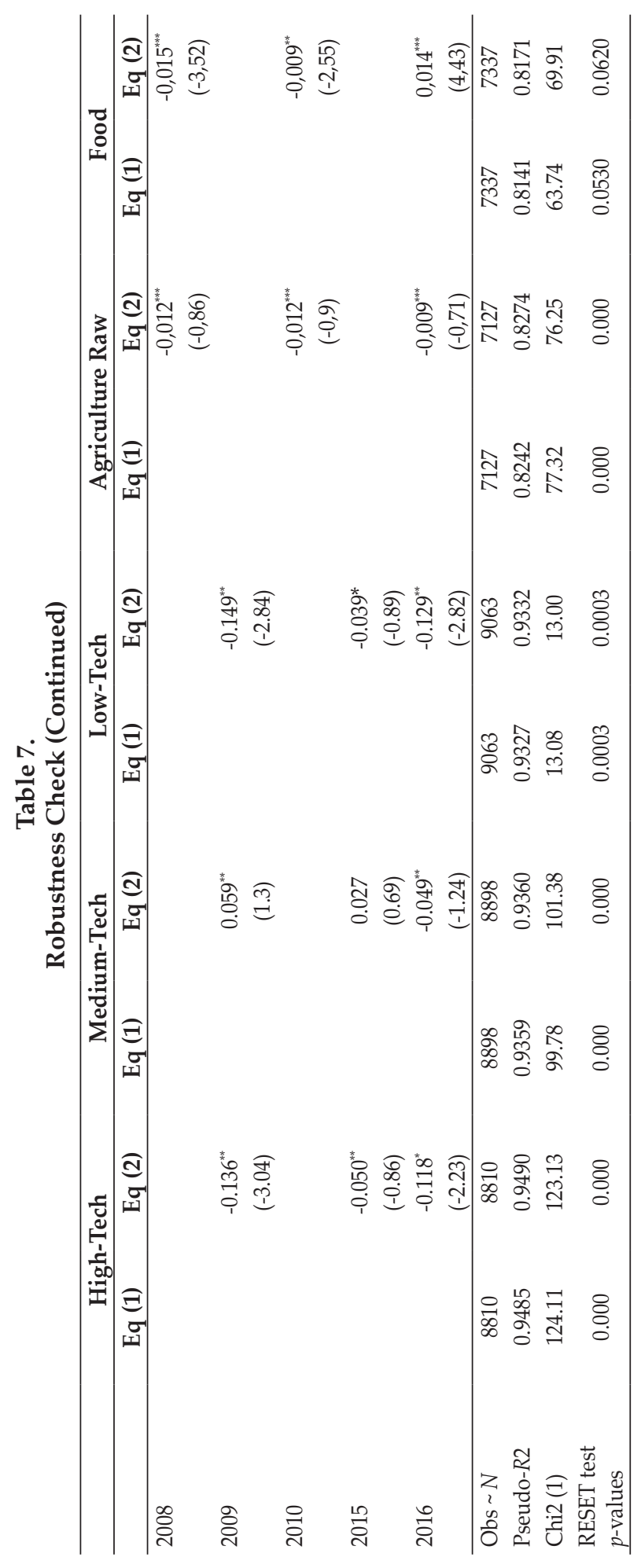


We first discuss results related to three core variables in the gravity model. We report that GDP for both exporter and importer countries has a positive and statistically significant effect on total exports of all five sub-categories products (high-tech, medium-tech, low-tech, food and agricultural goods). Additonally, we note that the magnitude of GDP effect for both importer and exporter countries in low-tech category are less than the magnitude observed for medium-to-high tech goods. The magnitude for low-tech goods are expected to be less than other categories because low-tech goods have more substitutes, are more costcompetitive, and require lower production installed capacity (see Urata and Okabe, 2014).

The second core variable in the gravity model is the total population. In the case of exporter countries, the relationship between total population and exports of medium-tech and low-tech products is positive and statistically significant. Large countries have more abundant possibilities for exports than smaller countries (Sen et al., 2015), therefore, a positive marginal effect of the population also allows for a broader scope of specialization. In other words, this suggests that large countries may capture more benefits from regional integration. On the other hand, the population of importers has a negative effect on exports of high-tech goods, suggesting that target markets are not entirely driven by the market size. High-tech goods are mainly differentiated and specialized, still largely exported to higher-income countries with smaller population as noted in Yang and MartinezZarzoso (2014).

The relationship between the third core variable distance between the capital cities of two trading partner countries, and export of products is negative and statistically significant in all five product sub-categories. This is consistent with our earlier findings reported for products aggregated as manufactured, natural resources- based and primary goods. Overall, we conclude that no matter how we categorise manufactured and non-manufactured goods into different subcategories, our results remain consistent with respect to all three core varaibles (namely GDP, population, and distance).

Our results with respect to the FTA dummy varaibles are also consistent with our earlier findings. For instance, we note that the dummy variable, intra-bloc trade (FTA1), has a statistically significant and positive impact on trade in the case of all sub-categories of products. Similar to our main findings, the sub-groups of products experienced lower than usual trade due to global shocks. Exports of high-tech and low-tech goods have a statistically significant and positive impact on non-bloc partners (captured using a dummy variable, FTA2). A positive FTA2 indicates a gain in welfare for extra-bloc countries.

Moreover, in the case of low-tech goods, the impact of imports from extrabloc is negative and statistically significant, suggesting trade diversion in imports. A negative sign on the FTA3 dummy variable indicates a shift from extra-bloc imports to intra-bloc. Trade diversion means the transfer of trade from treatymember countries to non-member countries (De Benedictis et al., 2005; Schaak, 2015). Urata and Okabe (2014) identified that a number of sub-sectors related to low tech goods experienced trade diversion impacts in ASEAN (e.g., textiles, apparel, cork, wood articles, among others). 
As for agricultural raw and food products, we find that raw agricultural goods experienced trade creation in exports and imports within the bloc and outside the bloc. Exports of food products experienced trade creation in intra-bloc flows, trade creation in imports from extra-bloc, and no evidence of export expansion with extra bloc. Our findings are consistent with the Indonesia-ASEAN case (Sugiharti et al., 2020), Australia-ASEAN Plus case (Timsina and Culas, 2019), and to a lesser extent to the China-ASEAN (Sun and Li, 2018; Yang and Martinez-Zarzoso, 2014).

Overall, we conclude that findings with respect to the signs on each of the core varaibles and the dummy varaibles are consistent irrespective of how products are grouped. The only thing that changes is the madnitude of effects, which is expected given the grouping categories.

\section{CONCLUSION}

This study analyzes whether the signing of ASEAN+6 FTA supports trade creation effects over the 2007 to 2017 period. A Poison Pseudo-Maximum Likelihood approach is employed to estimate the gravity model for 16 ASEAN Plus members and 22 non-partners for eight different groups of products.

The results indicate that the ASEAN+6 FTAs have led to trade creation effects for manufactured goods, natural resources-based, and primary commodities. Additionally, the FTA's supported the expansion of exports of manufactured goods and primary products to extra-FTA countries. Natural resources-based and primary goods experienced significant adverse effects in 2008, 2010 and 2016 due to product specific trade shocks, while trade related shocks in the case of manufactured goods are relatively lower. The ASEAN Plus mostly supported the intra-regional trade of manufactured products.

Once we disaggregate manufactured and non-manufactured products into five further product categories, the FTA's supported intra-bloc and extra-bloc exports of high and low-tech goods, although the FTA caused trade diversion in imports of low tech manufactured products. Medium-tech goods mainly expanded within the FTA-bloc. Agricultural raw goods experienced trade creation in exports in intra-bloc and trade creation in imports from extra-bloc, while food had pure trade creation.

The core variables in the gravity model show expected signs. The importer as a source of demand matters positively, as does the capacity of the producer country. Size of exporter matters on a larger scale for low-to-medium-tech and primary goods. The impact of distance on natural resources-based and primary goods is larger than on manufactured products. 


\section{REFERENCES}

Anderson, J. E. (1979). A Theoretical Foundation for The Gravity Equation. The American Economic Review, 69, 106-116.

Anderson, J. E., \& Van Wincoop, E. (2003). Gravity with Gravitas: A Solution to the Border Puzzle. American Economic Review, 93, 170-192.

Anderson, J. E., \& Yotov, Y. V. (2016). Terms of Trade and Global Efficiency Effects of Free Trade Agreements, 1990-2002. Journal of International Economics, 99, 279-298. https://doi.org/10.1016/j.jinteco.2015.10.006

Ando, M., \& Urata, S. (2007). The Impacts of East Asia FTA: A CGE Model Simulation Study. Journal of International Economic Studies, 11.

Baiardi, D., Bianchi, C., \& Lorenzini, E. (2015). Food Competition in World Markets: Some Evidence from a Panel Data Analysis of Top Exporting Countries. Journal of Agricultural Economics, 66, 358-391. https://doi.org/10.1111/1477-9552.12094

Baier, S. L., \& Bergstrand, J. H. (2004). Economic Determinants of Free Trade Agreements. Journal of International Economics, 64, 29-63. https://doi.org/10.1016/S0022-1996(03)00079-5

Baier, S. L., \& Bergstrand, J. H. (2007). Do Free Trade Agreements Actually Increase Members' International Trade? Journal of International Economics, 71, 72-95.

Baier, S. L., Yotov, Y. V., \& Zylkin, T. (2019). On the Widely Differing Effects of Free Trade Agreements: Lessons from Twenty Years of Trade Integration. Journal of International Economics, 116, 206-226. https://doi.org/10.1016/j.jinteco.2018.11.002

Bergstrand, J. H., Larch, M., \& Yotov, Y. V. (2015). Economic Integration Agreements, Border Effects, and Distance Elasticities in the Gravity Equation. European Economic Review, 78, 307-327. https://doi.org/10.1016/j.euroecorev.2015.06.003

Bhattacharyya, R., \& Mandal, A. (2014). Estimating the Impact of The IndiaASEAN Free Trade Agreement on Indian Industries. South Asia Economic Journal, 15, 93-114.

Bhattacharyya, R., \& Mandal, A. (2016). India-ASEAN Free Trade Agreement: An Ex Post Evaluation. Journal of Policy Modeling, 38, 340-352. https://doi.org/10.1016/j.jpolmod.2016.02.001

Carrere, C. (2006). Revisiting the Effects of Regional Trade Agreements on Trade Flows with Proper Specification of the Gravity Model. European Economic Review, 50, 223-247.

Cheong, J., Kwak, D. W., \& Tang, K. K. (2018). The Trade Effects of Tariffs qnd Non-Tariff Changes of Preferential Trade Agreements. Economic Modelling, 70, 370-382. https://doi.org/10.1016/j.econmod.2017.08.011

Crozet, M., Emlinger, C., \& Jean, S. (2015). On the Gravity of the Trade Slowdown. The Global Trade Slowdown: A New Normal? VoxEU and CEPR, 333.

Dai, M., Yotov, Y. V., \& Zylkin, T. (2014). On the Trade-Diversion Effects of Free Trade Agreements. Economics Letters, 122, 321-325. https://doi.org/10.1016/j.econlet.2013.12.024

De Benedictis, L., De Santis, R., \& Vicarelli, C. (2005). Hub-and-Spoke or Else? Free Trade Agreements in the'Enlaarged'European Union. The European Journal of Comparative Economics, 2, 245-261.

Deardorff, A. (1998). Determinants of Bilateral Trade: Does Gravity Work in a Neoclassical World? In the Regionalization of the World Ecomony (pp. 7-32). University of Chicago Press. 
Devadason, E. S., Subramaniam, T., \& Baharumshah, A. Z. (2015). Rebalancing Exports through Expansions in Intra-ASEAN Trade? Insights from Gravity Panel Estimates. Journal of Economic Cooperation and Development, 36, 77-106.

Eaton, J., \& Kortum, S. (2002). Technology, Geography, and Trade. Econometrica, 70, 1741-1779.

Esquivias Padilla, M. A., Handoyo, R. D., Sugiharti, L., \& Muryani, M. (2019). Production Networks under the ASEAN Plus Six. A Good Deal or a Threat? Entrepreneurship and Sustainability Issues, 7, 81-91. https://doi.org/10.9770/ jesi.2019.7.1(7)

Fally, T. (2015). Structural Gravity and Fixed Effects. Journal of International Economics, 97, 76-85.

Ghosh, S., \& Yamarik, S. (2004). Are Regional Trading Arrangements Trade Creating?: An Application of Extreme Bounds Analysis. Journal of International Economics, 63, 369-395. https://doi.org/10.1016/S0022-1996(03)00058-8

Gil-Pareja, S., Llorca-Vivero, R., \& Martínez-Serrano, J. A. (2014). Do Nonreciprocal Preferential Trade Agreements Increase Beneficiaries' Exports? Journal of Development Economics, 107, 291-304. https://doi.org/10.1016/j.jdeveco.2014.01.002

Head, K., \& Mayer, T. (2014). Gravity Equations: Workhorse, Toolkit, and Cookbook. Handbook of International Economics. Elsevier.

Hegerty, S. W. (2016). Commodity-Price Volatility and Macroeconomic Spillovers: Evidence from Nine Emerging Markets. The North American Journal of Economics and Finance, 35, 23-37. https://doi.org/10.1016/j.najef.2015.10.014

Khurana, R., \& Nauriyal, D. K. (2017). ASEAN-India Free Trade Agreement: Evaluating Trade Creation and Trade Diversion Effects. Journal of East-West Business, 23, 283-307. https://doi.org/10.1080/10669868.2017.1322548

Kimura, F., \& Obashi, A. (2016). Production Networks in East Asia: What We Know So Far. In G. Wignaraja (Eds.). Production Networks and Enterprises in East Asia: Industry and Firm-level Analysis (pp. 33-64). Springer Japan. https://doi.org/10.1007/978-4-431-55498-1_3

Kohl, T., Brakman, S., \& Garretsen, H. (2016). Do Trade Agreements Stimulate International Trade Differently? Evidence from 296 Trade Agreements. The World Economy, 39, 97-131. https://doi.org/10.1111/twec.12272

Korinek, J., \& Melatos, M. (2009). Trade Impacts of Selected Regional Trade Agreements in Agriculture. OECD. http://www.oecd-ilibrary.org/trade/trade-impacts-ofselectedregional-trade-agreements-in-agriculture_225010121752

Lall, S. (2000). The Technological Structure and Performance of Developing Country Manufactured Exports, 1985-98. Oxford Development Studies, 28, 337369.

Lemoine, F., \& Unal, D. (2017). China's Foreign Trade: A “New Normal.” China $\mathcal{E}$ World Economy, 25, 1-21.

López Gonzalez, J. (2016). Using Foreign Factors to Enhance Domestic Export Performance (OECD Trade Policy Papers, No. 191). OECD.

Magerman, G., Studnicka, Z., \& Van Hove, J. (2015). Distance and Border Effects in International Trade: A Comparison of Estimation Methods (Economics Discussion Papers, No. 69). Kiel Institute for the World Economy. http://www.economics-ejournal.org/economics/journalarticles/2016-18 
Martínez-Zarzoso, I., Felicitas, N.-L. D., \& Horsewood, N. (2009). Are Regional Trading Agreements Beneficial? The North American Journal of Economics and Finance, 20, 46-65. https://doi.org/10.1016/j.najef.2008.10.001

Oladi, R., \& Beladi, H. (2008). Is Regionalism Viable? A Case for Global Free Trade. Review of International Economics, 16, 293-300.

Pangestu, M., \& Ing, L. Y. (2016). ASEAN: Regional Integration and Reforms. Asian Economic Papers, 15, 44-60. https://doi.org/10.1162/ASEP_a_00424

Park, I. (2020). Regional Trade Agreements in East Asia: Past and Future. Development Policy Review, 38, 206-225. https://doi.org/10.1111/dpr.12418

Pieters, H., \& Swinnen, J. (2016). Trading-Off Volatility and Distortions? Food Policy During Price Spikes. Food Policy, 61, 27-39. https://doi.org/10.1016/j.foodpol.2016.01.004

Pöyhönen, P. (1963). A Tentative Model for the Volume of Trade Between Countries. Weltwirtschaftliches Archiv, 93-100.

Purwono, R., Esquivias, M. A., Sugiharti, L., Heriqbaldi, U., \& Handoyo, R. D. (2020). Value Chains, Production Networks and Regional Integration: The Case of Indonesia (Rantai Nilai, Jaringan Produksi dan Integrasi Wilayah: Kes Indonesia). Jurnal Ekonomi Malaysia, 54, 135 - 151. http://dx.doi.org/10.17576/JEM-2020-5401-10

Saucier, P., \& Rana, A. T. (2017). Do Preferential Trade Agreements Contribute to the Development of Trade? Taking Into Account the Institutional Heterogeneity. International Economics, 149, 41-56. https://doi.org/10.1016/j.inteco.2016.10.001

Schaak, H. (2015). The Impact of Free Trade Agreements on International Agricultural Trade: A Gravity Application on the Dairy Product Trade and the ASEAN-China-FTA. Perspektiven Für Die Agrar-Und Ernährungswirtschaft Nach Der Liberalisierung, 181.

Sen, R., Srivastava, S., \& Pacheco, G. (2013). The Early Effects of Preferential Trade Agreements on Intra-Regional Trade Within ASEAN+6 Members. Journal of Southeast Asian Economies, 30, 237-249.

Sen, R., Srivastava, S., \& Webber, D. (2015). Preferential Trading Agreements and the Gravity Model in Presence of Zero and Missing Trade Flows: Early Results for China and India (Working Paper, 2015-02). Auckland University of Technology.

Serrano, R., \& Pinilla, V. (2010). Causes of World Trade Growth in Agricultural and Food Products, 1951-2000: A Demand Function Approach. Applied Economics, 42, 3503-3518. https://doi.org/10.1080/00036840802167368

Sheng, Y., Tang, H. C., \& Xu, X. (2014). The Impact of The ACFTA on ASEAN-PRC Trade: Estimates Based on an Extended Gravity Model for Component Trade. Applied Economics, 46, 2251-2263. https://doi.org/10.1080/00036846.2014.899676

Silva, J. S., \& Tenreyro, S. (2006). The Log of Gravity. The Review of Economics and Statistics, 88, 641-658.

Soloaga, I., \& Winters, L. A. (2001). Regionalism in the Nineties: What Effect on Trade? The North American Journal of Economics and Finance, 12, 1-29. https://doi.org/10.1016/S1062-9408(01)00042-0

Sugiharti, L., Esquivias, M. A., \& Setyorani, B. (2020). The Impact of Exchange Rate Volatility on Indonesia's Top Exports to the Five Main Export Markets. Heliyon, 6, e03141. https://doi.org/10.1016/j.heliyon.2019.e03141 
Sugiharti, L., Purwono, R., \& Esquivias Padilla, M. A. (2020). Analysis of Determinants of Indonesian Agricultural Exports. Entrepreneurship and Sustainability Issues, 7, 2676-2695. https://doi.org/10.9770/jesi.2020.7.4(8)

Sun, Z., \& Li, X. (2018). The Trade Margins of Chinese Agricultural Exports to ASEAN and their Determinants. Journal of Integrative Agriculture, 17, 23562367. https://doi.org/10.1016/S2095-3119(18)62084-2

Taguchi, H. (2015). Trade Creation and Diversion Effects of ASEAN-Plus-One Free Trade Agreements. Economics Bulletin, 35, 1856-1866.

Timsina, K. P., \& Culas, R. J. (2019). Do Free Trade Agreements Increase Australian Trade: An Application of Poisson Pseudo Maximum Likelihood Estimator? Journal of East-West Business, 26, 56-80. https://doi.org/10.1080/10669868.2019.1685056

Tinbergen, J. J. (1962). Shaping the World Economy; Suggestions for an International Economic Policy. New York: Twentieth Century Fund.

Urata, S., \& Okabe, M. (2014). Trade Creation and Diversion Effects of Regional Trade Agreements: A Product-level Analysis. The World Economy, 37, 267-289.

Viner, J. (1950). The Customs Union Issue. Carnegie Endowment for International Peace. New York.

WTO. (2012). A Practical Guide to Trade Policy Analysis. World Trade Organization. https://doi.org/10.30875/131552a5-en

Yang, S., \& Martinez-Zarzoso, I. (2014). A Panel Data Analysis of Trade Creation and Trade Diversion Effects: The Case of ASEAN-China Free Trade Area. China Economic Review, 29, 138-151. 
This page is intentionally left blank 